\title{
Педіатрія
}

УДК $616-056.3-053.31$

®О. П. Волосовець, С. В. Врублевська

Національний медичний університет імені О. О. Богомольия, Київ

Запорізький державний медичний університет

\section{ПЕРВИННА ПРОФІЛАКТИКА АЛЕРГІЧНИХ ЗАХВОРЮВАНЬ У ДІТЕЙ НА ПЕРИНАТАЛЬНОМУ ЕТАПІ}

\begin{abstract}
ПЕРВИННА ПРОФІЛАКТИКА АЛЕРГІЧНИХ ЗАХВОРЮВАНЬ У ДІТЕЙ НА ПЕРИНАТАЛЬНОМУ ЕТАПІ. У СТОТТІ обґрунтовано доцільність використання алгоритму профілактики розвитку алергічних захворювань у дітей шляхом проведення організаційних заходів щодо поліпшення контролю якості харчової продукції, розробки раціональних підходів до режиму праці, відпочинку й, особливо, харчування вагітних жінок та жінок-годувальниць. Профілактичні заходи повинні виключити вплив та приймання ксенобіотиків як дієвий засіб первинної профілактики атопії в майбутньої дитини. Це дозволить зменшити рівень сенсибілізації плода, попередити ії формування та знизити рівень захворюваності на атопію в дітей.
\end{abstract}

ПЕРВИЧНАЯ ПРОФИЛАКТИКА АЛЛЕРГИЧЕСКИХ ЗАБОЛЕВАНИЙ У ДЕТЕЙ НА ПЕРИНАТАЛЬНОМ ЭТАПЕ. В СТАТЬЕ обоснована целесообразность использования алгоритма профилактики развития аллергических заболеваний у детей путем проведения организационных мероприятий по улучшению контроля качества пищевой продукции, разработки рациональных подходов к режиму труда, отдыха и, особенно, питания беременных женщин и кормящих женщин. Профилактические меры должны исключить влияние и употребление ксенобиотиков как действенное средство первичной профилактики атопии у будущего ребенка. Это позволит уменьшить уровень сенсибилизации плода, предупредить ее формирование и снизить уровень заболеваемости атопией у детей.

PRIMARY PREVENTION OF ALLERGIC DISEASES IN CHILDREN AT THE PERINATAL STAGE. In the article the rationale for the use of the algorithm prevention of allergic diseases in children by using organizational interventions to improve food quality control, development of rational approaches of work, rest and especially nutrition of pregnant women and lactating women. Preventive measures should eliminate the influence of xenobiotics and use as an effective means of primary prevention of atopy in the unborn child. This will reduce the level of sensitization of the fetus, to prevent its formation and reduce the incidence of atopy in children.

Ключові слова: алергія в дітей, фактори ризику, харчування вагітних, профілактика атопії.

Ключевые слова: аллергия у детей, факторы риска, питание беременных, профилактика атопии.

Key words: allergy in children, risk factors, nutrition of pregnant, prevention of atopy.

ВСТУП. Останнім часом істотно зросла роль техногенного впливу на організм людини, що зумовлює розповсюдження алергопатології серед дитячого населення. За даними МОЗ України (2013р.), всього по Україні зареєстровано 43930 хворих на бронхіальну астму дітей (5,5 на 1000 дитячого населення), тільки за 2013 р. зареєстровано 4502 нових випадки захворювання. Лідерами виявилися регіони 3 високою техногенною напругою: Донецька $(8,24$ на 1000 дітей), Запорізька (8,27 на 1000 дитячого населення), Дніпропетровська (7,11 на 1000 дітей), Харківська (7,70 на 1000 дитячого населення) області й м. Київ (9,36 на 1000 дітей). Негативний епігенетичний вплив на генотип людини призводить до реалізації генів, які відповідають за розвинення атопічних реакцій організму.

Проте протиставлення негативним епігенетичним факторам комплексу профілактичних заходів, на нашу думку, може попередити розвиток атопічних захворювань шляхом «виключення» (метилування) генів схильності до атопії (sCD14, TLR4, IL-10, IL-13, TNF-a). Тому розробка ефективних засобів профілактики розвитку алергопатології стає найбільш актуальною у вищезазначених регіонах.

Одними з основних епігенетичних факторів, які попереджують розвиток атопічних захворювань у дітей, є режим харчування матері протягом годування груддю, зменшення впливу негативних факторів на плід під час вагітності, грудне вигодовування немовляти [1-3]. Проте з необхідністю призначення гіпоалергенної дієти вагітним жінкам та матерям, які годують груддю, погоджуються не всі вчені. Так, експерти комітету ВООЗ із профілактики алергії вважають доречним гіпоалергенне харчування лише для тих вагітних жінок, які мають алергічні прояви захворювання, або тих, які завагітніли від чоловіків з ускладненнями в алергічному анамнезі [2].

У документі сумісного засідання експертів ВООЗ і Всесвітньої організації алергії «Запобігання алергії та алергічній астмі» (World Allergy Organization International Associationof Allergology and Clinical Immunology, WAO-IAACI) запропоновано три рівні, або напрями, заходів з профілактики формування алергії в дітей (О. М. Охотнікова, 2011; Ю. С. П'ятницький, 2006, Київ):

1. Первинна профілактика - запобігання сенсибілізації шляхом елімінації алергенів, також виключення впливу інших неспецифічних факторів, таких, як стрес, фізичне перевантаження, полютанти, іританти та ін. [1, 3].

2. Вторинна профілактика спрямована на запобігання розвитку клінічних проявів алергії у дітей 
(незважаючи на сенсибілізацію, яка вже відбулася) та полягає в ранній і своєчасній діагностиці сенсибілізації, коли хвороби ще немає.

3. Третинна профілактика проводиться вже за наявності розвиненого алергічного захворювання у будь-якому віці; вона спрямована на запобігання прогресуванню хвороби, незважаючи на клінічну маніфестацію, та включає усунення алергенів (харчових, пилкових, побутових) і неспецифічних тригерів (гостра респіраторно-вірусна інфекція, надмірне фізичне навантаження, метеорологічні умови, стресові ситуації), протизапальну базисну терапію. Найкращими засобами профілактики при цьому є елімінація причинних алергенів та проведення гіпосенсибілізації шляхом застосування антигістамінних препаратів або проведення СІT [4].

Таким чином, враховуючи, що алергія є проявом системного поліетіологічного запалення та характеризується етапністю формування алергічної відповіді, комплекс профілактичних заходів доцільно спрямовувати на основні ланки етіопатогенезу алергічного каскаду.

Метою дослідження було вивчити фактори ризику розвитку алергічного захворювання в майбутнього немовляти шляхом аналізу стану здоров'я вагітних жінок та розробити алгоритм профілактики розвитку алергопатологій у дітей.

МАТЕРІАЛИ ТА МЕТОДИ. Шляхом катамнестичного аналізу медичної документації (амбулаторних карт) 1210 вагітних жінок центру міста та 1310 вагітних, які проживають у зоні відносного екологічного благополуччя, ми відібрали пацієнток для проведення первинної профілактики атопічних захворювань у дітей на перинатальному етапі. За допомогою анкетування виявили вагітних жінок з високим ступенем ризику виникнення алергічного захворювання в майбутнього немовляти $(n=225)$. До групи дослідження відбирали вагітних жінок, які мали загострен- ня алергічного захворювання під час вагітності (п=225) або які завагітніли від чоловіків з атопічним захворюванням $(n=78)$. Адже встановлено, що ризик розвитку алергії у дитини за наявності проявів алергічного захворювання в обох батьків становить 40 $60 \%$. Якщо $*$ у обох батьків $€$ однакове алергічне захворювання, ризик збільшується до 80 \%. Якщо алергічне захворювання є тільки в одного з батьків або у сестри чи брата дитини, ризик становить 20-40\%, за наявності атопії в матері - 22-30\%, у батька 14-20\% [1, 2, 10]. До складу контрольної групи ввійшли вагітні жінки з необтяженим алергологічним анамнезом $(n=2520)$.

РЕЗУЛЬТАТИ ДОСЛІДЖЕННЯ ТАЇХ ОБГОВОРЕННЯ. При аналізі структури алергопатології вагітних жінок загазованого центру міста порівняно із зоною відносного благополуччя (найменш загазованим районом відносно розташування заводів) було виявлено, що загальний рівень алергопатології в 1,65 раза вищий у загазованій зоні - 11,23\% (п=136) проти 6,79\% (п=89). Проте кількість жінок з медикаментозною та харчовою алергією серед вагітних в обох зонах проживання майже однакова $(p<0,05$, діагр. 1).

Захворюваність на респіраторний алергоз у загазованій зоні в 4 рази вища (3,83 \% проти 0,91 \% вагітних), переважно за рахунок гіперчутливості до пилкових алергенів трав - також у 4 рази вища (3,58 \% проти $0,91 \%)$.

Проте при активному опитуванні за анкетою, розробленою ISAAC, було виявлено, що серед жінок 3 полінозом ( $=58)$ хоча б 1 раз у житті відчувала напад ядухи або його еквіваленти 21 хвора (у $36,21 \%$ випадків).

22,89 \% вагітних жінок (n=19) з 83 пацієнток 3 медикаментозною алергією мають прояви полінозу та $13,25 \%$ жінок (п=11) - симптоми цілорічного алергічного риніту. В 27,7 \% (5 випадків) харчова алергія

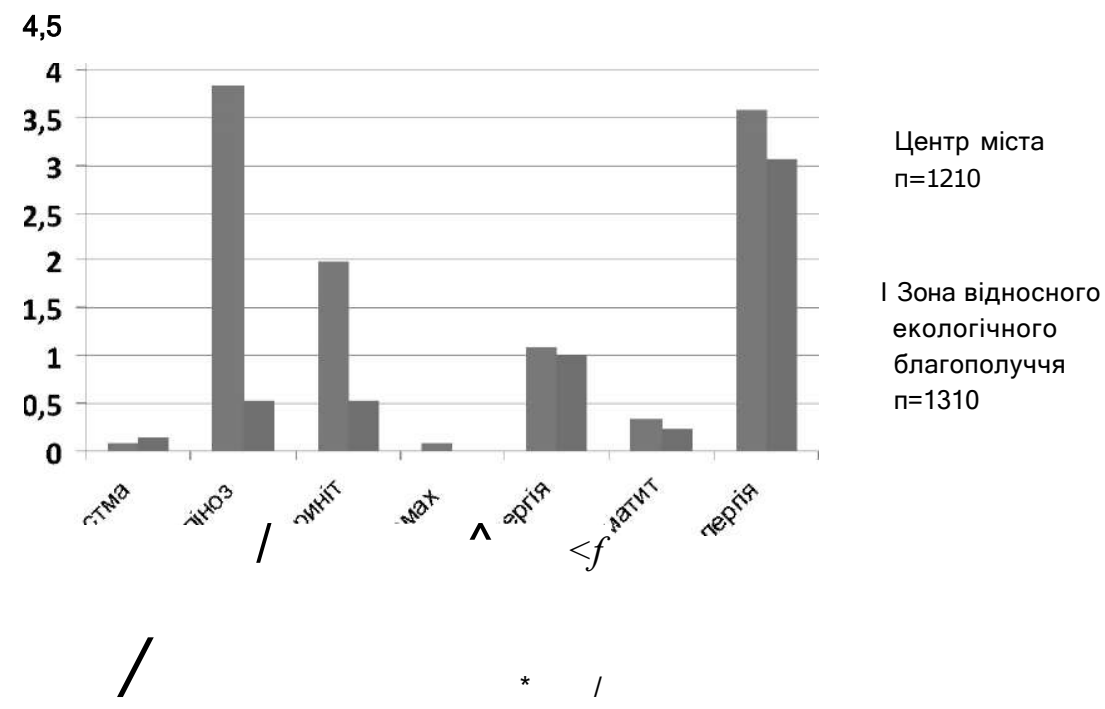

Діагр. 1. Структура алергопатології вагітних жінок загазованого центру міста порівняно із зоною відносного благополуччя. 


\section{Педіатрія}

супроводжувалась клінікою цілорічного алергічного риніту та у 22,22 \% випадків (п=18) - симптомами полінозу.

При опитуванні вагітних жінок щодо медикаментозної алергії терапевти робили акцент на виявленні алергічних реакцій на антибіотики, анестетики та НПВП. Статистично значущої відмінності серед вагітних жінок загазованого району порівняно з відносно сприятливою зоною не знайдено. Під час анкетування додатково було відзначено поодинокі випадки алергічних реакцій на естрогено-прогестероновмісні медикаменти (ультражестан), антигістамінні засоби (діазолін, супрастин, піпольфен), метопролол, преднізолон, антисептики. Структуру медикаментозної алергії вагітних жінок загазованого центру міста порівняно із зоною відносного благополуччя наведено в таблиці 1.

Гіперчутливість до алергенів пилу рідше зустрічалась: в обох групах порівняння - відповідно, у 2,5 та 2 рази менше, ніж поліноз. Проте в екологічно несприятливому районі в 3,5 раза частіше виявлялася гіперчутливість до побутових алергенів, ніж у зоні відносного благополуччя. Частоту виявлення сенсибілізації до різних видів алергенів серед вагітних жінок залежно від регіонального розташування показано на діаграмі 2.

Гіперчутливість до пилкових алергенів превалює за рахунок бур'янів - також у 4 рази вища в обох групах, ніж до пилку дерев та лугових трав, проте атопічні реакції на бур'яни у 4 рази частіше зустрічаються в загазованому районі міста $(3,58$ \% проти $0,91 \%)$. Алергічні реакції на епідермальні алергени тварин у центрі міста зареєстровані в 9 разів частіше, ніж у відносно чистому районі. Порівняльну характеристику ефективності виявлення алергічних захворювань серед вагітних жінок наведено в таблиці 2.

Аналіз оформлення документації щодо диспансеризації вагітних жінок показав, що частіше документально підтверджуються медикаментозна алергія, особливо на антибіотик та анестетик, контактний дерматит, ніж інші види алергічних захворювань. Респі-

Таблиця 1. Структура медикаментозної алергії вагітних жінок загазованого центру міста порівняно із зоною відносного благополуччя

\begin{tabular}{|l|c|c|}
\hline & $\begin{array}{c}\text { Центр міста } \\
n=136\end{array}$ & $\begin{array}{c}\text { Зона відносного екологічного благополуччя } \\
\text { п=89 }\end{array}$ \\
\hline Медикаментозна алергія & $43(3,583 \%)$ & $40(3,05 \%)$ \\
\hline - пеніциліни & $18(1,50 \%)$ & $16(1,22 \%)$ \\
\hline - інші АБ & $9(0,75 \%)^{*}$ & $5(0,38 \%)$ \\
\hline - анестетики & $7(0,583 \%)$ & $6(0,46 \%)$ \\
\hline - нестероїдні протизапальні препарати & $4(0,333 \%)$ & $7(0,53 \%)^{*}$ \\
\hline - вітаміни & $3(0,25 \%)$ & $5(0,38 \%)$ \\
\hline - препарати крові & $2(0,166 \%)$ & - \\
\hline Усього вагітних жінок & 1210 & 1310 \\
\hline
\end{tabular}

Примітки:

1. * $-p<0,05$.

2. ${ }^{* *}-\mathrm{p}<0,5$.

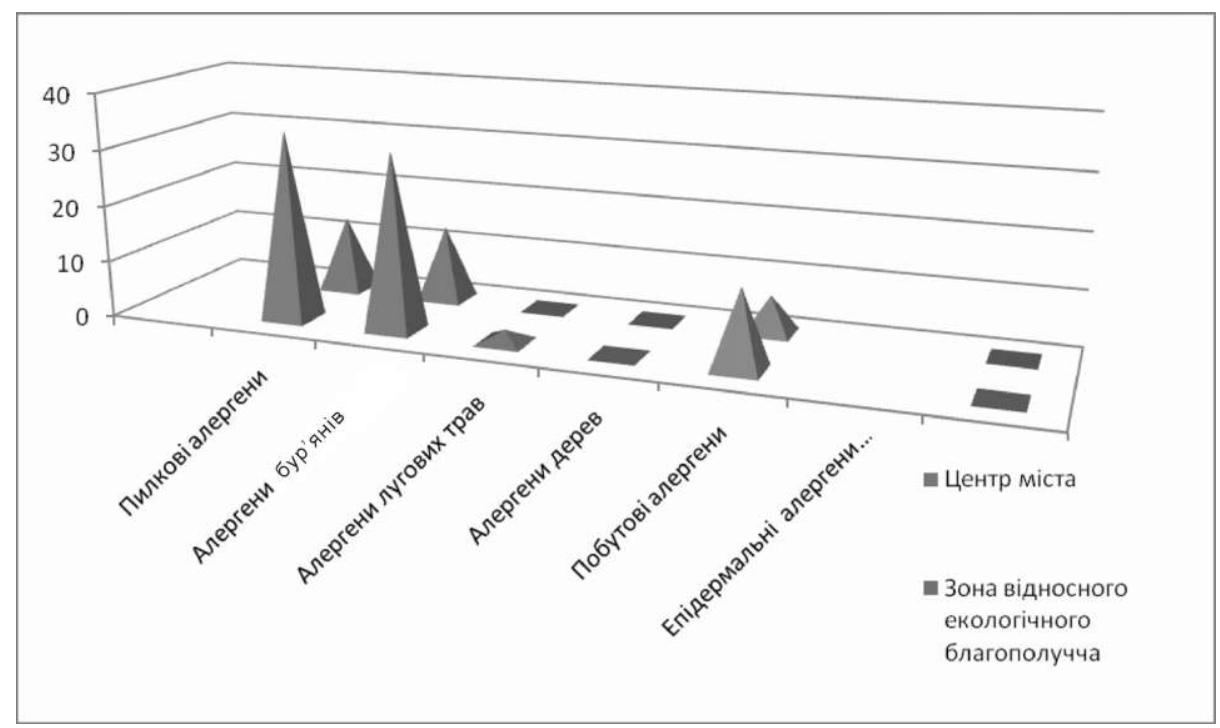

Діагр. 2. Частота виявлення сенсибілізації до різних видів алергенів серед вагітних залежно від регіонального розташування (за даними шкірного алерготестування). 
Таблиця 2. Порівняльна характеристика ефективності виявлення алергічних захворювань серед вагітних жінок

\begin{tabular}{|l|c|c|}
\hline & На основі даних опитування & $\begin{array}{c}\text { На основі даних, документально підтвердже- } \\
\text { них консультативним висновком алерголога }\end{array}$ \\
\hline Бронхіальна астма & $1(0,083 \%)$ & $2(0,15 \%)$ \\
\hline Поліноз & $46(3,83 \%)$ & $12(0,91 \%)$ \\
\hline- літньо-осінній & $43(3,58 \%)$ & - \\
\hline - весняний & $3(0,25 \%)$ & $12(0,91 \%)$ \\
\hline Гіперчутливість до побутових алергенів & $19(1,58 \%)$ & $1(., 076 \%)$ \\
\hline Епідермальні алергени & $5(0,416 \%)$ & \\
- кішки & $2(0,166 \%)$ & $15(1,14 \%)$ \\
- собаки & $1(0,083 \%)$ & $3(0,23 \%)$ \\
- дафнп (корм для риб) & $1(0,083 \%)$ & $40(3,05 \%)$ \\
\hline Укуси комах & $13(1,083 \%)$ & $16(1,22 \%)$ \\
\hline Харчова алергія & $4(0,333 \%)$ & $5(0,38 \%)$ \\
\hline Контактний дерматит & $43(3,583 \%)$ & $6(0,46 \%)$ \\
\hline Медикаментозна алергія & $18(1,50 \%)$ & $7(0,53 \%)$ \\
\hline - пеніциліни & $9(0,75 \%)$ & $5(0,38 \%)$ \\
\hline - інші АБ & $7(0,583 \%)$ & - \\
\hline - анестетики & $4(0,333 \%)$ & 1310 \\
\hline - нестероїдні протизапальні препарати & $3(0,25 \%)$ & \\
\hline - вітаміни & $2(0,166 \%)$ & \\
\hline- препарати крові & 1210 & \\
\hline Усього вагітних за рік & & \\
\hline
\end{tabular}

раторний алергоз, підтверджений даними алерготестування, зареєстрований у 3,61 раза рідше, ніж виявлений при опитуванні в кабінеті акушера-гінеколога та терапевта.

Цікавий факт: серед 345 матерів, новонароджені діти яких отримували стаціонарне лікування у відділенні патології новонароджених обласної дитячої клінічної лікарні (всі - жителі сільської місцевості), обтяжений алергологічний анамнез відзначено тільки у 3-х. В їх дітей протягом перших 2-х діб лікування виявлені клінічні симптоми харчової алергії без підвищення загального рівня $\mathrm{lgE}$, на фоні тривалої антибіотикотерапії внутрішньоутробної інфекції неуточненої етіології цефалоспоринами 3-ї генерації.

Додаткове опитування за анкетою, розробленою ISAAC, виявило, що серед жінок з полінозом $(n=58)$ хоча б 1 раз у житті відчувала напад ядухи або його еквіваленти 21 хвора (у 36,21 \% випадків), 22,89\% вагітних жінок $(n=19)$ з 83 пацієнток з медикаментозною алергією мають прояви полінозу та 13,25 \% жінок (n=11) - симптоми цілорічного алергічного риніту. В 27,7 \% (5 випадків) харчова алергія супроводжувалась клінікою цілорічного алергічного риніту та у 22,22 \% випадків $(n=4)$ - симптомами полінозу. Тому ми вважаємо, що треба посилити роботу поліклінічних відділень жіночих консультацій з виявлення і профілактики алергічних захворювань у вагітних жінок. Це дозволить відстрочити сенсибілізацію плода і запобігти розвитку алергічних реакцій у майбутньої дитини.

Відомо, що алергени (антигени) в організмі людини розпізнаються Т-лімфоцитами (ТИ2-клітинами). Зрілі циркулюючі Т-лімфоцити виявляються у плода 3 18-го тижня внутрішньоутробного розвитку. Під впливом несприятливих епігенетичних факторів у геномі плода знижується метилування ДНК в локусі ТИ2-клітин протягом диференціювання 3 наївних Т-клітин, що корелює зі збільшенням ацетиляції гістонів і підвищенням експресії IL-4, IL-5 і IL-13 (В. А. Козлов, 2012), тому материнські антигени за рахунок проникнення 3 амніотичної рідини через шкіру та шлунково-кишковий тракт плода можуть спричиняти сенсибілізацію плода уже на ранніх стадіях.

Несприятливий вплив забрудненого довкілля, профшкідливості, шкідливі звички, споживання напівсинтетичних продуктів, хронічні інфекційні та соматичні захворювання батьків, напружений емоційний фон можуть негативно впливати на епігеном дитини та у подальшому формувати «матрицю» розвитку алергічних захворювань, особливо в екологічно несприятливих регіонах, тому профілактику алергічних захворювань у майбутнього немовляти, на нашу думку, треба починати з антенатального періоду.

У відомих експериментах, проведених у 20092010 рр. в Університеті Дьюка (Північна Кароліна / США), Ренді Джіртлу (RandyJirtle, 2010) і Роберту Уотерленду (RobertWaterland) вдалося радикально змінити фенотип мишей-носіїв мутації агути. Такі миші мають характерне жовте забарвлення, ожиріння, схильні до діабету та раку. Додаючи в їжу самкамагути за два тижні до спаровування і під час вагітності речовини-донори метальних груп (вітамін $\mathrm{B}_{12}$, фолієву кислоту, метіонін і холін), вчені виявили, що на світ з'являються мишенята з нормальним бурим кольором шерсті. Протягом усього життя вони мали також нормальну масу і були здорові. Пояснити таку реверсію до нормального фенотипу можна тільки тим, що зміна материнського раціону харчування вимкнула дефектний ген, незважаючи на те, що жодна буква в «спадковій інструкції» не була переписана.

Ми пропонуємо такий комплекс профілактичних заходів:

Первинна антенатальна профілактика.

Заходи первинної профілактики повинні базуватися на виключенні з режиму життя майбутньої ма- 


\section{Педіатрія}

тері й новонародженої дитини найбільш вірогідних алергенів. Найчастіше, згідно з результатами специфічної алергодіагностики іп vitro, харчову сенсибілізацію у новонароджених спричинюють коров'яче молоко (50 \%), мандарини $(21,4 \%)$, риба $(17,9 \%)$, куряче яйце $(10,7 \%)$, гречана $(7,1 \%)$ та рисова $(7,1 \%)$ крупи, апельсини (7,1 \%). Перинатальні чинники розвитку алергії у новонароджених: обтяжений алергологічний (60-80\%) і акушерський анамнези (пізні гестози - 24,3 \%; затяжні пологи та пологи шляхом кесаревого розтину - 11,4 \%), поліпрагмазія під час вагітності (55\%), при годуванні груддю (70\%; антибіотики - 14-15\%, вітаміни - 10-14\%) та в новонароджених (18,7\%), комплекс несприятливих антенатальних факторів, порушення мікроекології організму $(55,2$ \%), зловживання жінкою облігатними алергенами під час вагітності $(41,4 \%)$ та годування груддю $(28,5 \%)$, пізнє прикладання до груді $(64,3 \%)$, ранній перехід на штучне вигодовування $(15,7 \%)$, змішане та штучне вигодовування (40\%), шкідливі звички батьків (5,7 \%) [5]. Тому комплекс первинної антенатальної профілактики, на нашу думку, повинен включати формування харчової толерантності, зниження гострої респіраторної та гельмінтно-паразитарної захворюваності.
До комплексу первинної профілактики ми включили: дотримування гіпоалергенної дієти, уникнення професійних шкідливостей; виключення тютюнокуріння, споживання алкогольних напоїв, інших шкідливих звичок, обмеження застосування фармакологічних засобів; зниження рівня експозиції екзогенними алергенами (алергенами домашнього пилу, особливо пилових кліщів Dermatophagoides pteronyssinus, $D$. farinae); уникнення вірусних і бактеріальних інфекцій; лікування ускладнення вагітності, супутніх алергічних та інших соматичних хвороб [1].

Всім вагітним жінкам, і здоровим, і тим, які належать до групи ризику щодо виникнення алергії, ми рекомендуємо виключити 3 харчування облігатні алергени і гістаміно-лібератори (полуницю, томати, какао, шоколад, цитрусові, креветки та ін.); продукти, багаті на екстрактивні речовини (м'ясні та рибні бульйони) й ефірні олії (цибулю, часник), сіль, спеції і прянощі (рибні делікатеси, закусочні консерви, ковбаси, сосиски), а також продукти з низькою харчовою цінністю, які містять водночас консерванти, синтетичні барвники та ароматизатори (безалкогольні прохолодні напої, деякі види кондитерських виробів). Для порівняння в таблиці 3 наведено набір продуктів для здорових вагітних і жінок, які годують грудним молоком.

Таблиця 3. Асортимент продуктів, рекомендованих і не рекомендованих вагітним жінкам та жінкам-годувальницям з груп ризику щодо розвитку в їх дітей харчової алергії (І. Я. Конь, М. В. Гмошинська, Москва, 2005)

\begin{tabular}{|c|c|c|c|}
\hline $\begin{array}{c}\text { Група } \\
\text { продуктів }\end{array}$ & $\begin{array}{l}\text { Допускаються в кількості, реко- } \\
\text { мендованій для здорових жінок }\end{array}$ & Обмежуються & Виключаються \\
\hline 1 & 2 & 3 & 4 \\
\hline $\begin{array}{l}\text { М'ясо та м'я- } \\
\text { сопродукти }\end{array}$ & $\begin{array}{l}\text { Яловичина, свинина м'ясна, нежир- } \\
\text { на, м'ясо кролика, індички, курчат, } \\
\text { курки * }\end{array}$ & $\begin{array}{l}\text { Ковбаси варені, м'ясні делікате- } \\
\text { си, сосиски, сардельки не часті- } \\
\text { ше двох разів на тиждень }\end{array}$ & $\begin{array}{l}\text { Сиро- і варенокопчені ковбаси, заку- } \\
\text { сочні консерви }\end{array}$ \\
\hline $\begin{array}{l}\text { Риба і рибо- } \\
\text { продукти }\end{array}$ & Тріска, хек, мінтай, судак, окунь & $\begin{array}{l}\text { Оселедець слабосолоний, жирні } \\
\text { сорти риби (камбала, палтус) не } \\
\text { частіше одного разу на тиждень }\end{array}$ & $\begin{array}{l}\text { Скумбрія, морепродукти (раки, краби, } \\
\text { креветки, крабові палички), закусочні } \\
\text { консерви }\end{array}$ \\
\hline Яйця & - & До 3 шт. на тиждень & - \\
\hline $\begin{array}{l}\text { Молоко і мо- } \\
\text { лочні продук- } \\
\text { ти }\end{array}$ & $\begin{array}{l}\text { Кисломолочні продукти без арома- } \\
\text { тизаторів і фруктових наповнюва- } \\
\text { чів (кефір, ряжанка, йогурти, кисле } \\
\text { молоко), негострий сир, сметана, } \\
\text { козяче молоко та сир з нього }\end{array}$ & $\begin{array}{l}\text { Молоко, вершки, кисломолочні } \\
\text { продукти з ароматизаторами і } \\
\text { фруктовими наповнювачами, гла- } \\
\text { зуровані сирки }\end{array}$ & \\
\hline $\begin{array}{l}\text { Крупи, мака- } \\
\text { ронні вироби }\end{array}$ & $\begin{array}{l}\text { Гречана, кукурудзяна, рисова, вів- } \\
\text { сяна крупи, макарони }\end{array}$ & & \\
\hline $\begin{array}{l}\text { Хліб і хлібобу- } \\
\text { лочні вироби }\end{array}$ & $\begin{array}{l}\text { Пшеничний, житньо-пшеничний, } 3 \\
\text { висівками, сушки, сухарі }\end{array}$ & $\begin{array}{l}\text { Здобні хлібобулочні вироби, біск- } \\
\text { віти не частіше двох разів на тиж- } \\
\text { день }\end{array}$ & \\
\hline Харчові жири & $\begin{array}{l}\text { Рафіновані рослинні олп: соняшни- } \\
\text { кова, кукурудзяна, соєва, оливко- } \\
\text { ва, вершкове масло }\end{array}$ & Маргарин вершковий & Майонез, кулінарні жири \\
\hline $\begin{array}{l}\text { Цукор і конди- } \\
\text { терські виро- } \\
\text { би }\end{array}$ & $\begin{array}{l}\text { Галети, печиво (нездобне), зефір, } \\
\text { пастила }\end{array}$ & $\begin{array}{l}\text { Цукор (до } 40 \text { г на добу) або ва- } \\
\text { рення, повидло, джеми з яблук, } \\
\text { груш в еквівалентній кількості }\end{array}$ & $\begin{array}{l}\text { Торти, тістечка з кремом, шоколад, } \\
\text { шоколадні цукерки, мед, варення, } \\
\text { джеми, повидло з полуниці, цитрусо- } \\
\text { вих, тропічних фруктів, винограду }\end{array}$ \\
\hline Овочі & $\begin{array}{l}\text { Картопля, капуста білокачанна і } \\
\text { цвітна, кольрабі, буряк, кабачки, } \\
\text { патисони, огірки, гарбуз, морква * }\end{array}$ & & Томати \\
\hline Фрукти & Яблука, груші & $\begin{array}{l}\text { Абрикоси*, персики*, диня*, виш- } \\
\text { ня*, черешня*, смородина*, слива* }\end{array}$ & $\begin{array}{l}\text { Банани, цитрусові, тропічні плоди, } \\
\text { виноград, полуниця, малина }\end{array}$ \\
\hline
\end{tabular}




\begin{tabular}{|l|l|l|l|}
\hline \multicolumn{1}{|c|}{1} & \multicolumn{1}{|c|}{2} & \multicolumn{1}{|c}{ Продовження табл. 3 } \\
\hline Соки і напої & $\begin{array}{l}\text { Соки натуральні, переважно яблуч- } \\
\text { ний та грушевий, фруктові напої, } \\
\text { чай, питна бутильована вода }\end{array}$ & $\begin{array}{l}\text { Соки та нектари абрикосовий, } \\
\text { персиковий, сливовий, вишне- } \\
\text { вий }\end{array}$ & $\begin{array}{l}\text { Соки томатний, апельсиновий, вино- } \\
\text { граднй, 3 тропічних фруктів, з полу- } \\
\text { ниці та малини, безалкогольні газова- } \\
\text { ні й негазовані прохолодні напої, ка- } \\
\text { као, пиво (в тому числі безалкоголь- } \\
\text { не), алкогольні напої }\end{array}$ \\
\hline
\end{tabular}

Примітка. * - за умови переносимості.

Відповідно до наказу МОЗ України № 417 від 05.07.2011 р. [11], всім вагітним жінкам і породіллям, які годують дитину грудним молоком, овочі та фрукти рекомендується їсти декілька разів на день (більше 500 г/день). Співвідношення овочів до фруктів -2:1. Середні витрати організму - 2200-2300 ккал/добу. Для повного насичення тканин для вагітних добова потреба у вітаміні С складає 50 мг, фолієвій кислоті - 400 мкг тільки до 12 тижнів вагітності, кальції $300 \mathrm{Mr}$, щоденна доза йоду, рекомендована ВООЗ, ЮНІСЕФ і Міжнародною радою з контролю за йододефіцитними захворюваннями, - 200 мг, вітаміну D - 10 мкг або 400 МО. Жінки з достатніми запасами заліза в організмі не потребують додаткового призначення заліза, добова потреба - 30 мг на день. Відмічено тератогенний ефект від приймання вітаміну А в дозі більш ніж 10000 ОД на добу (A) з особли- вим акцентом на відсутності необхідності рутинного приймання вітаміну $D$, заліза, йоду, полівітаміно-мінеральних комплексів (А). Необхідно використовувати консерви тільки для дитячого харчування - овочеві, фруктові, м'ясні, рибні (табл. 4).

Як показали у своїх дослідженнях І. Я. Конь, М. В. Гмошинська (Москва, 2012), крім високоалергенних продуктів, причиною розвитку алергічних реакцій можуть стати будь-які продукти, використані у великій кількості й постійно. Саме тому з метою профілактики алергії ми рекомендуємо вагітним жінкам і матерям-годувальницям урізноманітнити свій раціон, застосовувати різні продукти, не віддавати переваги будь-якому продукту. В таблиці 5 наведено середньодобові набори продуктів харчування для матерів-годувальниць і вагітних жінок з груп ризику щодо розвитку харчової алергії в їх дітей.

Таблиця 4. Продукти харчування, харчові добавки й лікарські препарати, що спричинюють розвиток псевдоалергічних реакцій (AДАІР, 2005)

\begin{tabular}{|c|c|c|}
\hline ІнНЯ & Харчова добавка & кий засіб \\
\hline $\begin{array}{l}\text { Консервація, копченості, квашені та марино- } \\
\text { вані продукти, кава, какао, шоколад, цитрусо- } \\
\text { ві, риба та рибні продукти, продукти моря, } \\
\text { томати, капуста, горіхи, гриби, насіння, вина, } \\
\text { ферментовані сири, суниця, полуниця, печін- } \\
\text { ка, свинина та ін. }\end{array}$ & $\begin{array}{l}\text { Барвники, приправи, аромати- } \\
\text { затори, консерванти, емульга- } \\
\text { тори, стабілізатори, розрихлю- } \\
\text { вачі, імітатори смаку, антиокис- } \\
\text { лювачі та ін. }\end{array}$ & $\begin{array}{l}\text { Папаверин, атропін, нестероїдні протизапа- } \\
\text { льні засоби, препарати, які містять бром, } \\
\text { йод, антибіотики, засоби для наркозу, віта- } \\
\text { міни, препарати, що містять солі жовчних } \\
\text { кислот, білкові препарати, препарати крові } \\
\text { та ін. }\end{array}$ \\
\hline
\end{tabular}

Таблиця 5. Середньодобові набори продуктів харчування для матерів-годувальниць і вагітних жінок з груп ризику щодо розвитку харчової алергії в їх дітей (АДАІР, Ю. С. Смолкин, 2010) [7]

\begin{tabular}{|l|c|c|}
\hline \multicolumn{1}{|c|}{ Продукт (кількість (г), брутто } & $\begin{array}{c}\text { Для здорових матерів-годувальниць / } \\
\text { вагітних жінок }\end{array}$ & $\begin{array}{c}\text { Для матерів-годувальниць / вагітних } \\
\text { жінок із групи ризику }\end{array}$ \\
\hline \multicolumn{1}{|c|}{1} & 2 & 3 \\
\hline Хліб пшеничнй & $150 / 120$ & $150 / 120$ \\
\hline Хліб житній & $100 / 100$ & 0 \\
\hline Борошно пшеничне & $20 / 15$ & $60 / 50$ \\
\hline Крупи, макаронні вироби & $70 / 60$ & $200 / 200$ \\
\hline Картопля & $200 / 200$ & $400 / 400$ \\
\hline Овочі & $500 / 500$ & $300 / 300$ \\
\hline Фрукти & $300 / 300$ & $150 / 150$ \\
\hline Соки & $150 / 150$ & $18 / 20$ \\
\hline Сухофрукти & $18 / 20$ & $40 / 40$ \\
\hline Цукор & $60 / 60$ & $20 / 20$ \\
\hline Кондитерські вироби & $20 / 20$ & $165 / 170$ \\
\hline М'ясо, птиця & $165 / 170$ & $70 / 70$ \\
\hline Риба & $70 / 70$ & $0 / 0$ \\
\hline Молоко коров'яче & $200 / 200$ & $200 / 200$ \\
\hline Молоко козяче & $0 / 0$ & \\
\hline
\end{tabular}




\section{Педіатрія}

\begin{tabular}{|l|c|c|}
\multicolumn{1}{|c|}{1} & \multicolumn{2}{|c|}{ Продовження табл. 5 } \\
\hline $\begin{array}{l}\text { Кефір та інші кисломолочні продукти } \\
2,5 \% \text { жирності }\end{array}$ & $400 / 300$ & $400 / 300$ \\
\hline Сир 9 \% жирності & & $50 / 50$ \\
\hline Сметана 10 \% жирності & $50 / 50$ & $15 / 17$ \\
\hline Масло вершкове & $10 / 17$ & $20 / 15$ \\
\hline Олія рослинна & $25 / 25$ & $20 / 25$ \\
\hline Яйця, шт. & $15 / 15$ & $0,5 / 0,5$ \\
\hline Сир & $0,5 / 0,5$ & $15 / 15$ \\
\hline Чай & $15 / 15$ & $1 / 1$ \\
\hline Кава & $1 / 1$ & $3 /-$ \\
\hline Сіль & $3 /-$ & $8 / 5$ \\
\hline Хімічний склад & $8 / 5$ & $100 / 92$ \\
\hline Білок, г & & $60 / 60$ \\
\hline У тому числі твариннй, г & $104 / 96$ & $93 / 90$ \\
\hline Жир, г & $60 / 60$ & $30 / 28$ \\
\hline У тому числі рослинний, г & $93 / 90$ & $330 / 300$ \\
\hline Вуглеводи, г & $25 / 23$ & $2557 / 2378$ \\
\hline Енергетична цінність, ккал & $370 / 340$ & \\
\hline
\end{tabular}

Уникнення поліпрагмазії при призначенні протиалергічних препаратів з істотним негативним впливом на плід під час загострення атопічного захворювання у вагітної жінки дозволить проаналізувати існуючі протиалергічні засоби. Перше покоління седативні, атропіноподібні, з ефектом тахіфілаксії, потребують біотрансформації у печінці;друге покоління - неседативні, без тахіфілаксії, проте з ризиком подовження інтервалу електрокардіограми QT та кардіотоксичною дією, яка виникає в разі одночасного приймання з протигрибковими засобами, макролідами, антидепресантами, грейпфрутовим соком і при виражених порушеннях функції печінки; третє покоління - активні метаболіти антигістамінних препаратів другого покоління 3 відсутністю седативного та кардіотоксичного ефектів, із найбільш високою біодоступністю, практично не метаболізуються в організмі, що знижує ризик небажаних реакцій і лікарських взаємодій: дезлоратадін, фексофенадін, левоцетирізін (Відаль, 2012). Антигістамінні препарати третього покоління найбільш безпечні для використання під час вагітності, якщо передбачувана користь для матері перевищує потенційний ризик для плода.

ВИСНОВКИ. Враховуючи викладене, необхідно використовувати принципи епігенетичного підходу для розробки профілактичних заходів на рівні держави та регіонів, які попереджатимуть розвиток ато- пічних захворювань у дітей, зокрема з відповідними організаційними заходами щодо поліпшення контролю якості харчової продукції, розробки раціональних підходів до режиму праці, відпочинку та, особливо, харчування вагітних жінок і жінок-годувальниць, що повинно виключити вплив та приймання ксенобіотиків як дієвий засіб первинної профілактики атопії у майбутньої дитини. Це дозволить зменшити рівень сенсибілізації плода, попередити ії формування та знизити рівень захворюваності на атопію у дітей.

ПЕРСПЕКТИВИ ПОДАЛЬШИХ ДОСЛІДЖЕНЬ. МИ призначили вищезазначений комплекс профілактичних засобів вагітним жінкам, які мали загострення алергічного захворювання під час вагітності $(n=225)$ або які завагітніли від чоловіків з атопічним захворюванням $(\mathrm{n}=78)$.

Геном ідентичний у клітинах різних типів протягом всього життя, проте під впливом навколишнього середовища активуються одні й «виключаються» інші гени. Виключення споживання напівсинтетичних продуктів, збільшення відсотка овочів, фруктів, рослинних олій, які мають антиоксидантну дію і зменшують вплив ксенобіотиків на організм людини, посилюють функції систем очищення організму (нирок, печінки), дозволять зменшити ризик виникнення атопічних захворювань (з режиму виключаються чинники, спроможні активувати ацетилювання генів схильності до атопії).

\section{СПИСОК ЛІТЕРАТУРИ}

1. Охотнікова О. М. Профілактика алергії у дітей: сучасні можливості та перспективи / О. М. Охотнікова // Дитячий лікар. - 2011. - № 4. - С. 26-35.

2. Костроміна В. П. Етапи профілактики алергійних захворювань у дітей / В. П. Костроміна, В. О. Стриж // Дитячий лікар. - 2010. - № 2. - С. 48-50.
3. Шумна Т. Є. Сучасні погляди на лікування та профілактику алергічних захворювань у дітей / Т. Є. Шумна // Здоровье ребенка. - 2011. - № 6. - С. 33.

4. Беш Л. В. Профілактика алергічних захворювань у дітей: наскільки можливою вона є сьогодні? / Л. В. Беш // Дитячий лікар. - 2009. - № 1. - С. 7-13. 


\section{Педіатрія}

5. Куля О. О. Перинатальні чинники ризику розвитку алергіїу немовлят : дис ....канд. мед. наук : 14.01.10/ Куля О. О. ; Львівський національний медичний ун-т ім. Данила Галицького. - Львів, 2004. - 19 с.

6. Рылеева И. В. Профилактика аллергических болезней у детей / И. В. Рылеева // Детская аллергология : руководство для врачей / под ред. А. А. Баранова, И. И. Балаболкина. - М., 2006. - С. 631-642.

7. Смолкин Ю. С. Сучасні підходи до організації раціонального харчування вагітних жінок і годуючих матерів : методичні рекомендації, затверджені Комітетом охорони здоров'я м. Москви // Ю. С. Смолкин. 2002. - № 4 .
8. Allergic Diseases and Environment / Eds. E. Isolauri, W.A. Walker. - Basel, 2004. - p.324

9. International consensus conference on atopic dermatitis II (ICAAD II): clinical update and current treatment strategies / C. Ellis, T. Luger, D. Abeck [et al.] Br. J. Dermatol. - 2003. - Vol 148 (Suppl. 63). - P. 3-10.

10. Role of probiotics in food hypersensitivity / Isolari E., RautavaS., Kalliomaki M. [et al.] Curr. Opin. Allergy ClinImmunol - 2002. - Vol. 2. - P. 263-271.

11. Про організацію амбулаторної акушерськогінекологічної допомоги в Україні : наказ МОЗ України № 417 від 05.07.2011 р. 